\title{
Studies on Genetic variability, Heritability and Genetic Advance in Groundnut (Arachis hypogaea L.) Genotypes under Normal and Osmotic Stress in In vitro Condition
}

\author{
M. Shankar ${ }^{1 *}$, B.N. Harish Babu' ${ }^{2}$, R. Gobu ${ }^{1}$ and Sheshaiah ${ }^{1}$ \\ ${ }^{1}$ College of Agriculture, Shivamogga, University of Agricultural and Horticultural Sciences, \\ Shivamogga, Karnataka, India \\ ${ }^{2}$ College of Horticulture, Hiriyur, Chitradurga (Dist), University of Agricultural and \\ Horticultural Sciences, Shivamogga, Karnataka, India \\ *Corresponding author
}

\section{A B S T R A C T}

\begin{tabular}{|l|}
\hline Ke y w or d s \\
Groundnut, PEG- \\
6000, GCV, PCV, \\
Heritability, \\
Drought tolerance \\
\hline Article Info \\
\hline $\begin{array}{l}\text { Accepted: } \\
\text { 07 April } 2019 \\
\text { Available Online: } \\
\text { 10 May } 2019\end{array}$ \\
\hline
\end{tabular}

The present investigation was carried out in 49 groundnut genotypes to assess the nature and extent of genetic variability, heritability and genetic advance under normal (0\% polyethylene glycol-6000 as control) and osmotic stress condition (15\% polyethylene glycol-6000) in germination phases in three replications in a completely randomized design. The observations on germination per cent, root length, shoot length, fresh weight of seedlings and total dry matter were recorded on tenth day after incubation. Further, seed vigour, root to shoot ratio, root length stress tolerance index and plant height stress tolerance index were computed to understand the drought tolerance ability of the genotypes. The results of the analysis of variance for all the characters studied were found to be highly significant in both the conditions indicating the availability of huge variability. A high range of variation and high heritability coupled with high genetic advance was recorded for most of the traits. This indicates the broad genetic base and less environmental influence which specifies the predominance of genetic factor controlling variability. Hence, early generation selection schemes would be effective for improvement and there is an ample scope for isolation of promising lines from the present gene pool for drought tolerance.

\section{Introduction}

Groundnut (Arachis hypogaea L.) is the fourth most important oilseed crop and thirteenth most important food crop in the world (Cuc et al., 2008; Coulibaly et al., 2013). The crop is being successfully grown in tropical and sub-tropical regions of the world as a result of its adaptability to a wide range of soil and climatic conditions. Groundnut is popularly called as peanut, earthnut, wondernut, monkey nut, manila nut and etc. In India, it is known by many local names viz., Moongphali (Hindi), Shenga (Kannada), Verusenagalu (Telugu), Nilakadalai (Tamil), Mandavi (Gujarati) and so on. 
Groundnut $(2 \mathrm{n}=40)$ has emerged as an economically important crop due to its significant share in vegetable oil production of India. Abiotic stress has been reported as a major constrain for groundnut production and recent abrupt climate change is making the abiotic stresses more common in the country. Water stress severely affects growth and development at all growth stages of plant.

Agronomic interventions poses their own importance in abiotic stress tolerance, since genetic solutions are unlikely to close more than 30 per cent of the gap between potential and realized yield under water stress (Edmeades et al., 2004). Though, enhanced genetics can be easily packaged in a seed and therefore more effortlessly and completely adopted than improved agronomic practices that depend more heavily on input availability, infrastructure, and skills in crop and soil management (Campos et al., 2004). So, the use of genetics and plant breeding aspects to improve drought tolerance and provide yield stability is an important part of the solution to stabilizing global groundnut production.

However, the crop improvement for water stress requires incessant efforts chiefly, through the knowledge of genetic mechanism governing heritable character. Genetic effects of heritable character lead a plant breeder to an obvious understanding of inheritance patterns of various plant characters as their relative contribution to the absolute yield.

Efficient improvement of any crop depends chiefly on the information on genetic variability and diversity which outlines the basis for any crop breeding programme. Further, the triumph of any crop improvement programme depends on the amount of genetic variability present in the population for the character for which the improvement is designed at. So, screening the germplasm lines and cultivated varieties for drought tolerance is the initial step in developing cultivars with both high yield and drought tolerance. However, drought tolerance screening under field conditions needs lot of resources like land, labor, rain-free environment and planning of the experiment. Further, it also depends on the environmental influences that change phenotypic expression of a genotype.

The study of effect of drought stress by using osmotic solutions in germinal stage is one of the alternative methods for drought tolerance screening. Plants tolerant to the abiotic stresses can be obtained by applying the selective agents such as $\mathrm{NaCl}$, for salt tolerance, mannitol or polyethylene glycol (PEG), for drought tolerance (Errabii et al., 2008).

Polyethylene glycol is a superior choice for imposing low water potential as like similar to drying soil than the frequently employed solute mannitol, for the reason that mannitol has been shown to be taken up by plant cells and can cause specific toxic effects on growth and development (Hohl and Schopfer, 1991; Verslues et al., 1998).

Screening genotypes at seedling phase is found to have several benefits, such as screening large set of germplasm with more accuracy, less effort, low cost, less laborious, ease of handling and getting clear of susceptible genotypes at an early stage. In addition, seedling characters have also shown moderate to high heritability with additive type of genetic variance within and over environments (Rauf et al., 2009).

Several authors reported the use of polyethylene glycol (PEG-6000) for in vitro drought screening in crop plants (Gobu et al., 2014). Moreover, seedling characters have also revealed moderate to high heritability 
with additive form of genetic variance over and within environments (Rauf et al., 2009). There are very little reports available on the genetics of drought tolerance in groundnut. Hence, in this study we made an attempt to know the nature and extent of genetic variability, heritability and genetic advance of characters concerned in drought tolerance.

\section{Materials and Methods}

The research materials used in the study consisted of 49 genotypes (Table 1). They were screened under drought stress (induced osmotic stress) and non-stress (normal) conditions (Plate 1). Each of the 49 genotypes was subjected to osmotic stress at germination stage induced by Polyethylene Glycol-6000 (PEG-6000) at $15.0 \%$ (equivalent to - 3 bars, as described by Michel and Kaufmann, 1973) in 3 replications in a completely randomized design as reported by Shankar et al., (2016). For control, sterile distilled water was used instead of PEG-6000 for seed germination and seedling growth.

Ten seeds per genotype per replication were surface sterilized with 70 per cent ethanol for 1 minute. Later, the seeds were rinsed thoroughly with distilled water for three times and seeds were put up in petri-plates having

$$
\begin{aligned}
\text { Root length stress tolerance index }= & \frac{\text { Root length of stressed seedlings }(\mathrm{cm})}{\text { Root length of control seedlings }(\mathrm{cm})} \times 100 \\
\text { Plant height stress tolerance index }= & \frac{\text { Plant height of stressed seedlings }(\mathrm{cm})}{\text { Plant height of control seedlings }(\mathrm{cm})} \times 100
\end{aligned}
$$

The statistical analysis of the data on the individual characters was carried out on the mean values of ten random plants and analyzed by using Windostat software package (Version 9.2). The analysis of variance for each character was analyzed by adopting Completely Randomized Design as suggested by Cochran and Cox (1957). The mean, range and variance values of each character were calculated for each genotype. wet germination paper. Seeds were moistened with distilled water for control petri-plates and with $15 \%$ PEG-6000 solution for treatment petri-plates and were incubated for 10 days at room temperature. At periodic interval, $1 \mathrm{ml}$ of distilled water or PEG-6000 solution was added to petri-plates to manage the germination paper adequately moist during the period of incubation. Seed germination was taken on day to day basis. The observations on germination per cent, seedling length, shoot length, root length, fresh weight of seedlings and total dry matter were noted on 10th day after incubation (Plate 1). Further, root to shoot ratio, seed vigour, plant height stress tolerance index and root length stress tolerance index, were estimated to have a greater understanding on their drought tolerance potentiality. Seed vigor was determined using the following formula (ISTA, 1985).

Seed vigour $=$ Germination percentage $\times$ Seedling length $(\mathrm{cm})$.

Root length stress tolerance index (RLSI) and plant height stress tolerance index (PLSI) were calculated as given by Ashraf et al., (2006) using the consecutive formula:
The coefficient of variation both at phenotypic and genotypic levels for all the characters were computed by applying the formula as suggested by Burton and Devane (1953). PCV and GCV were classified into low $(0-10 \%)$, moderate $(11-20 \%)$ and high (21\% and above) as suggested by Subramanian and Menon (1973). Heritability in broad sense for all the characters was computed by the formula suggested by 
Hanson et al., (1956). Heritability was classified into low $(0-30 \%)$, moderate $(31-$ $60 \%)$ and high (61 \% and above) as suggested by Robinson et al., (1949). The predicted genetic advance was estimated according to the formula given by Johnson and Robinson (1955). The genetic advance as per cent of mean was categorized into low (0 $-10 \%)$, moderate $(10.1-20 \%)$ and high (> 20.1 and above) as suggested by Johnson and Robinson (1955).

\section{Results and Discussion}

Analysis of variance was done to test the significance differences among genotypes studied in both moisture stress (15\% PEG$6000)$ and normal condition (0 \% PEG-6000). Analysis of variance revealed that, the genotypes under study differed significantly even at one per cent level of probability for all characters studied in both moisture stress and normal conditions. The mean sum of squares of all the characters is presented in Tables 2 and 3 for moisture stress and normal (without moisture stress) conditions, respectively.

Comparison between phenotypic co-efficient of variation and genotypic co-efficient of variation for all the characters studied under stress and normal condition is represented in figure 1. Comparison between broad sense heritability and genetic advance over mean for all the characters studied in in vitro screening under stress and normal condition is represented in figure 2 . The estimate of various genetic parameters under osmotic stress and normal condition is given in tables 3 and 4 respectively.

\section{Germination per cent}

The mean germination percentage under moisture stress induced by $15 \%$ PEG-6000 was in the range of 70.00 to 82.00 with an overall mean of 78.70 per cent. On the other hand, under normal condition (0\% PEG), the mean germination per cent recorded was 99.32 with a range of 93.33 to 100 per cent. Germination per cent in both control and stress situation showed low phenotypic coefficient of variation (PCV) and genotypic coefficients of variation (GCV) coupled with a moderate heritability. This trait showed low genetic advance over mean (GAM) in both control and stress conditions. This result clearly depicts that the germination percentage can be used as selection criterion in groundnut for drought tolerance. These results are in agreement with that of Shankar et al., (2016), Gobu et al., (2014), Saensee et al., (2012), Contamutto et al., (2010), Ahmad et al., (2009), Iqbal and Asraf (2006), Kaya et al., (2006) and El-Midaoui (2003) as for as the use of PEG-6000 for drought stress tolerance in different crop plants.

\section{Root length}

Under moisture stress condition (15\% PEG$6000)$, the mean root length recorded was $5.83 \mathrm{~cm}$ with a range of 2.81 to $8.64 \mathrm{~cm}$. However, under normal condition, the root length ranged from 1.31 to $6.72 \mathrm{~cm}$ with a mean of $3.30 \mathrm{~cm}$. The phenotypic and genotypic co-efficient of variability in both stressed and control condition were high with high heritability and high genetic advance over mean. This clearly indicates that, there exists a possibility of this trait being under the influence of additive gene action which provides a better scope for selection of genotypes for drought tolerance based on increased root length under moisture stress environments.

\section{Shoot length}

The mean shoot length under moisture stress was $2.40 \mathrm{~cm}$ and ranged from 2.12 to 2.79 $\mathrm{cm}$. But under normal condition, the mean 
shoot length recorded was $5.75 \mathrm{~cm}$ with a range of 3.81 to $9.60 \mathrm{~cm}$. This character showed low genotypic and phenotypic coefficients of variability under moisture stress condition. But, it exhibit high genotypic and phenotypic coefficients of variability in control condition. It possesses high heritability under both moisture stress and non-stress conditions. However, the genetic advance over mean was moderate (under stress condition) to high (under control) indicating the possibility of selection for this trait both under control and stress conditions.

\section{Root to shoot ratio}

The mean root to shoot ratio under moisture stress was 2.43 and it was in the range of 1.20 to 3.68. Under normal condition, the root to shoot ratio was in the range of 0.34 to 1.02 with a mean of 0.58 . This trait exhibited moderate genotypic and phenotypic coefficients of variation in stressed condition whereas it has recorded high genotypic and phenotypic coefficients of variation under control condition. Further, this trait has shown high heritability with high genetic advance over mean and is known to play a pivotal role in drought tolerance.

\section{Seed vigour}

The seed vigour under moisture stress was in the range of 383.41 to 900.35 with a mean of 648.92. However, under normal condition, the mean seed vigour was 899.19. The lowest and the highest seed vigour were recorded 512.02 and 1549.68 , respectively.

Seed vigour exhibited moderate genotypic and phenotypic coefficients of variation in stressed condition in comparison to their higher values under control condition. This trait seems to be less influenced by environmental factors as indicated by high heritability and high genetic advance over mean.

\section{Fresh weight of the seedlings}

The minimum and maximum fresh weights of the seedlings under moisture stress were 5.06 and $10.69 \mathrm{mg}$, respectively with a mean of $7.18 \mathrm{mg}$. The fresh weight of the seedlings under normal condition ranged from 8.52 to $19.62 \mathrm{mg}$ with a mean of $13.02 \mathrm{mg}$. The GCV and PCV for fresh weight under both control and stressed were moderate besides having high heritability coupled with high genetic advance over mean.

\section{Dry weight of the seedlings}

Under the moisture stress induced by $15 \%$ PEG-6000, the dry weight of the seedlings ranged from 2.51 to $5.73 \mathrm{mg}$ with a mean of $3.83 \mathrm{mg}$. In case of normal condition, the mean dry weight of the seedlings was $3.98 \mathrm{mg}$ and ranged from 2.95 to $6.58 \mathrm{mg}$. However, the dry weight of the seedlings in both stressed and control condition showed moderate genotypic and phenotypic coefficients of variability akin to fresh weight of groundnut seedlings in the present investigation. Further, it also showed similar tendency to that of fresh weight of seedlings in having high heritability along with high genetic advance over mean.

\section{Plant height stress tolerance index (PHSI) and Root Length Stress Tolerance Index (RLSI)}

The mean PHSI ranged between 25.43 and 59.83 with an overall mean of 43.57. The RLSI observed was 196.38 and it ranged from 69.25 to 468.67 .

Root length stress tolerance index (RLSI) showed high genotypic and phenotypic coefficients of variability whereas plant height stress tolerance index (PHSI) showed a moderate values for these two genetic parameters. 
Table.1 List of groundnut genotypes used in the present investigation

\begin{tabular}{|c|c|c|c|c|c|c|c|c|c|}
\hline Sl. No. & Genotypes & \multicolumn{2}{|c|}{ Pedigree } & Sl. No. & Genotypes & Pedigree & Sl. No & Genotypes & Pedigree \\
\hline 1 & Dh-241 & \multicolumn{2}{|c|}{ UAS,D } & 18 & UAS,D -1 & UAS,D & 35 & KCG-2 & UAS,B \\
\hline 2 & Dh-235 & \multicolumn{2}{|c|}{ UAS,D } & 19 & R-2001-3 & UAS, R & 36 & VB-T13 & UAS,B \\
\hline 3 & Dh-234 & \multicolumn{2}{|c|}{ UAS,D } & 20 & VB-T4 & UAS,B & 37 & VB & UAS,B \\
\hline 4 & Dh-243 & \multicolumn{2}{|c|}{ UAS,D } & 21 & KCG-6 & UAS,B & 38 & VB-T18 & UAS,B \\
\hline 5 & Dh-245 & \multicolumn{2}{|c|}{ UAS,D } & 22 & SB-T1 & UAS,B & 39 & SB-T3 & UAS,B \\
\hline 6 & Dh-246 & \multicolumn{2}{|c|}{ UAS,D } & 23 & SB-T17 & UAS,B & 40 & SB-T40 & UAS,B \\
\hline 7 & Dh-247 & \multicolumn{2}{|c|}{ UAS,D } & 24 & VB-T11 & UAS,B & 41 & VB-T35 & UAS,B \\
\hline 8 & Dh-216 & \multicolumn{2}{|c|}{ UAS,D } & 25 & VB-T14 & UAS,B & 42 & SB-T2 & UAS,B \\
\hline 9 & K-6 & \multicolumn{2}{|c|}{ UAS,B } & 26 & SB-T7 & UAS,B & 43 & SB-T10 & UAS,B \\
\hline 10 & K-9 & \multicolumn{2}{|c|}{ UAS,B } & 27 & SB-T14 & UAS,B & 44 & SB-T21 & UAS,B \\
\hline 11 & ICGV-91115 & \multicolumn{2}{|c|}{ UAS,B } & 28 & UAS,D -2 & UAS,D & 45 & VB-T3 & UAS,B \\
\hline 12 & Dh-101 & \multicolumn{2}{|c|}{ UAS,D } & 29 & UAS,D -3 & UAS,D & 46 & SB-T11 & UAS,B \\
\hline 13 & G2-52 & \multicolumn{2}{|c|}{ UAS,D } & 30 & SB-T15 & UAS,B & 47 & VB-T7 & UAS,B \\
\hline 14 & GPBD-4 & \multicolumn{2}{|c|}{ UAS,D } & 31 & ICGV-91114 & UAS,B & 48 & SB-T16 & UAS,B \\
\hline 15 & Dh-86 & \multicolumn{2}{|c|}{ UAS,D } & 32 & VB-T31 & UAS,B & 49 & SB-T8 & UAS,B \\
\hline 16 & TMV-2 & \multicolumn{2}{|c|}{ UAS,B } & 33 & SB-T12 & UAS,B & & & \\
\hline 17 & GPBD-5 & \multicolumn{2}{|c|}{ UAS,D } & 34 & SB-T13 & UAS,B & & & \\
\hline \multicolumn{10}{|c|}{ Where, } \\
\hline & UAS, Bangalore & - & \multicolumn{5}{|c|}{ University of Agricultural Sciences, Bangalore, Karnataka. } & & \\
\hline & UAS, Dharwad & - & \multicolumn{5}{|c|}{ University of Agricultural Sciences, Dharwad, Karnataka. } & & \\
\hline & UAS, Raichur & - & \multicolumn{5}{|c|}{ University of Agricultural Sciences, Raichur, Karnataka. } & & \\
\hline & VB & - & \multicolumn{5}{|c|}{ Valencia Bunch } & & \\
\hline & SB & - & \multicolumn{5}{|c|}{ Spanish Bunch } & & \\
\hline
\end{tabular}


Table.2 Analysis of variance in groundnut genotypes under moisture stress induced by $15 \%$ PEG-6000 in in vitro experiment

\begin{tabular}{|l|c|c|c|c|c|c|c|c|c|c|}
\hline \multicolumn{1}{|c|}{ Source } & d.f. & $\begin{array}{c}\text { Germinatio } \\
\text { n per cent }\end{array}$ & $\begin{array}{c}\text { Root } \\
\text { length } \\
\text { (cm) }\end{array}$ & $\begin{array}{c}\text { Shoot } \\
\text { length } \\
\text { (cm) }\end{array}$ & $\begin{array}{c}\text { Root to } \\
\text { shoot } \\
\text { ratio }\end{array}$ & $\begin{array}{c}\text { Seed } \\
\text { vigour }\end{array}$ & $\begin{array}{c}\text { Fresh } \\
\text { weight } \\
\text { (mg) }\end{array}$ & $\begin{array}{c}\text { Dry } \\
\text { weight } \\
\text { (mg) }\end{array}$ & RLSI & PHSI \\
\hline Genotypes & 48 & $17.44^{* *}$ & $4.76^{* *}$ & $0.07 * *$ & $0.74 * *$ & 62735.91 & $3.16^{* *}$ & $1.37 * *$ & $18065.96 * *$ & $220.26^{* *}$ \\
\hline Error & 98 & 6.62 & 0.045 & 0.004 & 0.01 & 1529.34 & 0.10 & 0.03 & 106.49 & 3.09 \\
\hline S.Em & & 1.49 & 0.11 & 0.04 & 0.06 & 22.58 & 0.18 & 0.10 & 5.96 & 1.01 \\
\hline CV\% & & 3.27 & 3.22 & 2.74 & 4.29 & 4.89 & 4.45 & 4.56 & 5.26 & 4.03 \\
\hline CD5\% & & 4.17 & 0.30 & 0.11 & 0.17 & 63.37 & 0.52 & 0.28 & 16.72 & 2.85 \\
\hline CD1\% & & 5.52 & 0.40 & 0.14 & 0.22 & 83.88 & 0.69 & 0.38 & 22.13 & 3.77 \\
\hline
\end{tabular}

Table.3 Analysis of variance in groundnut genotypes under normal condition (0 \% PEG-6000) in in vitro experiment

\begin{tabular}{|l|c|c|c|c|c|c|c|c|}
\hline Source & d.f. & $\begin{array}{c}\text { Germinatio } \\
\text { n per cent }\end{array}$ & $\begin{array}{c}\text { Root length } \\
\text { (cm) }\end{array}$ & $\begin{array}{c}\text { Shoot } \\
\text { length }(\mathbf{c m})\end{array}$ & $\begin{array}{c}\text { Root to } \\
\text { shoot ratio }\end{array}$ & Seed vigour & $\begin{array}{c}\text { Fresh } \\
\text { weight (mg) }\end{array}$ & $\begin{array}{c}\text { Dry weight } \\
(\mathbf{m g})\end{array}$ \\
\hline $\begin{array}{l}\text { Genoty } \\
\text { pes }\end{array}$ & 48 & $12.47^{* *}$ & $3.80^{* *}$ & $5.49^{* *}$ & $0.076^{* *}$ & $150942.76^{* *}$ & $21.64^{* *}$ & $1.63 * *$ \\
\hline Error & 98 & 3.40 & 0.01 & 0.02 & 0.001 & 685.36 & 0.29 & 0.03 \\
\hline S.Em & & 1.07 & 0.06 & 0.09 & 0.015 & 15.12 & 0.31 & 0.10 \\
\hline CV\% & & 1.86 & 3.13 & 2.71 & 4.64 & 2.91 & 4.11 & 4.05 \\
\hline CD5\% & & 2.99 & 0.17 & 0.25 & 0.04 & 42.42 & 0.87 & 0.26 \\
\hline CD1\% & & 3.96 & 0.22 & 0.33 & 0.06 & 56.16 & 1.15 & 0.35 \\
\hline
\end{tabular}

Where,

**-Significance@1\%,

d.f. - Degrees of freedom
*-Significance @ 5\%

RLSI - Root length stress tolerance index
PHSI - Plant height stress tolerance index

Table.4 Estimates of genetic parameters in groundnut genotypes under moisture stress induced by $15 \%$ polyethylene glycol-6000 (PEG-6000) in in vitro experiment

\begin{tabular}{|c|c|c|c|c|c|c|c|}
\hline Sl.No. & Character & Mean & Range & $\operatorname{PCV}(\%)$ & GCV (\%) & $h^{2}(\%)$ & GAM (\%) \\
\hline 1 & Germination (\%) & 78.70 & $70.00-82.00$ & 4.60 & 2.41 & 35.25 & 2.95 \\
\hline 2 & Root length (cm) & 5.83 & $2.81-8.64$ & 21.75 & 21.51 & 97.81 & 43.82 \\
\hline 3 & Shoot length $(\mathrm{cm})$ & 2.40 & $2.12-2.79$ & 6.84 & 6.27 & 83.95 & 11.83 \\
\hline 4 & Root to shoot ratio & 2.43 & $1.20-3.68$ & 20.78 & 20.33 & 95.74 & 40.98 \\
\hline 5 & Seed vigour & 648.92 & $383.41-900.35$ & 17.49 & 16.99 & 94.36 & 33.99 \\
\hline 6 & Fresh weight (mg) & 7.18 & $5.06-10.69$ & 14.74 & 14.06 & 90.89 & 27.60 \\
\hline 7 & Dry weight (mg) & 3.83 & $2.51-5.73$ & 18.02 & 17.43 & 93.60 & 34.74 \\
\hline 8 & RLSI & 196.38 & $69.25-468.67$ & 39.75 & 39.40 & 98.25 & 80.45 \\
\hline 9 & PHSI & 43.57 & $25.43-59.83$ & 19.94 & 19.53 & 95.91 & 39.40 \\
\hline \multicolumn{8}{|c|}{ Where, } \\
\hline & \multicolumn{3}{|c|}{ RLSI - Root length stress tolerance index } & \multicolumn{4}{|c|}{ PHSI - Plant height stress tolerance index } \\
\hline & \multicolumn{3}{|c|}{ PCV - Phenotypic coefficient of variation } & \multicolumn{4}{|c|}{ GCV - Genotypic coefficient of variation } \\
\hline & \multicolumn{3}{|c|}{$h^{2}-$ Broad sense heritability } & \multicolumn{4}{|c|}{ GAM - Genetic advance as per cent over mean } \\
\hline
\end{tabular}


Table.5 Estimates of genetic parameters in groundnut genotypes under normal condition (0\% PEG-6000) in in vitro experiment

\begin{tabular}{|c|c|c|c|c|c|c|c|}
\hline Sl.No. & Character & Mean & Range & $\operatorname{PCV}(\%)$ & GCV (\%) & $h^{2}(\%)$ & GAM (\%) \\
\hline 1 & Germination (\%) & 99.32 & $93.33-100.00$ & 2.55 & 1.75 & 47.06 & 2.47 \\
\hline 2 & Root length (cm) & 3.30 & $1.31-6.72$ & 34.19 & 34.04 & 99.16 & 34.88 \\
\hline 3 & Shoot length $(\mathrm{cm})$ & 5.75 & $3.81-9.60$ & 34.19 & 23.46 & 98.69 & 48.01 \\
\hline 4 & Root to shoot ratio & 0.58 & $0.34-1.02$ & 27.93 & 27.54 & 97.25 & 55.95 \\
\hline 5 & Seed vigour & 899.19 & $512.02-1549.68$ & 25.06 & 24.89 & 98.65 & 50.92 \\
\hline 6 & Fresh weight (mg) & 13.02 & $8.52-19.61$ & 20.90 & 20.49 & 96.14 & 41.38 \\
\hline 7 & Dry weight (mg) & 3.98 & $2.95-6.58$ & 18.80 & 18.36 & 95.36 & 36.94 \\
\hline Where, & & \multirow{2}{*}{\multicolumn{3}{|c|}{$\begin{array}{l}\text { GCV - Genotypic coefficient of } \\
\text { variation }\end{array}$}} \\
\hline & \multicolumn{4}{|c|}{ PCV - Phenotypic coefficient of variation } & & & \\
\hline & \multicolumn{4}{|c|}{$h^{2}-$ Broad sense heritability } & \multicolumn{3}{|c|}{$\begin{array}{l}\text { GAM - Genetic advance as per cent } \\
\text { over mean }\end{array}$} \\
\hline
\end{tabular}

Fig.1 Comparison between phenotypic coefficient of variation (PCV) and genotypic coefficient of variation $(\mathrm{GCV})$ for all the characters studied in in vitro screening under stress (15\% PEG6000) and normal condition (0 \% PEG--6000)

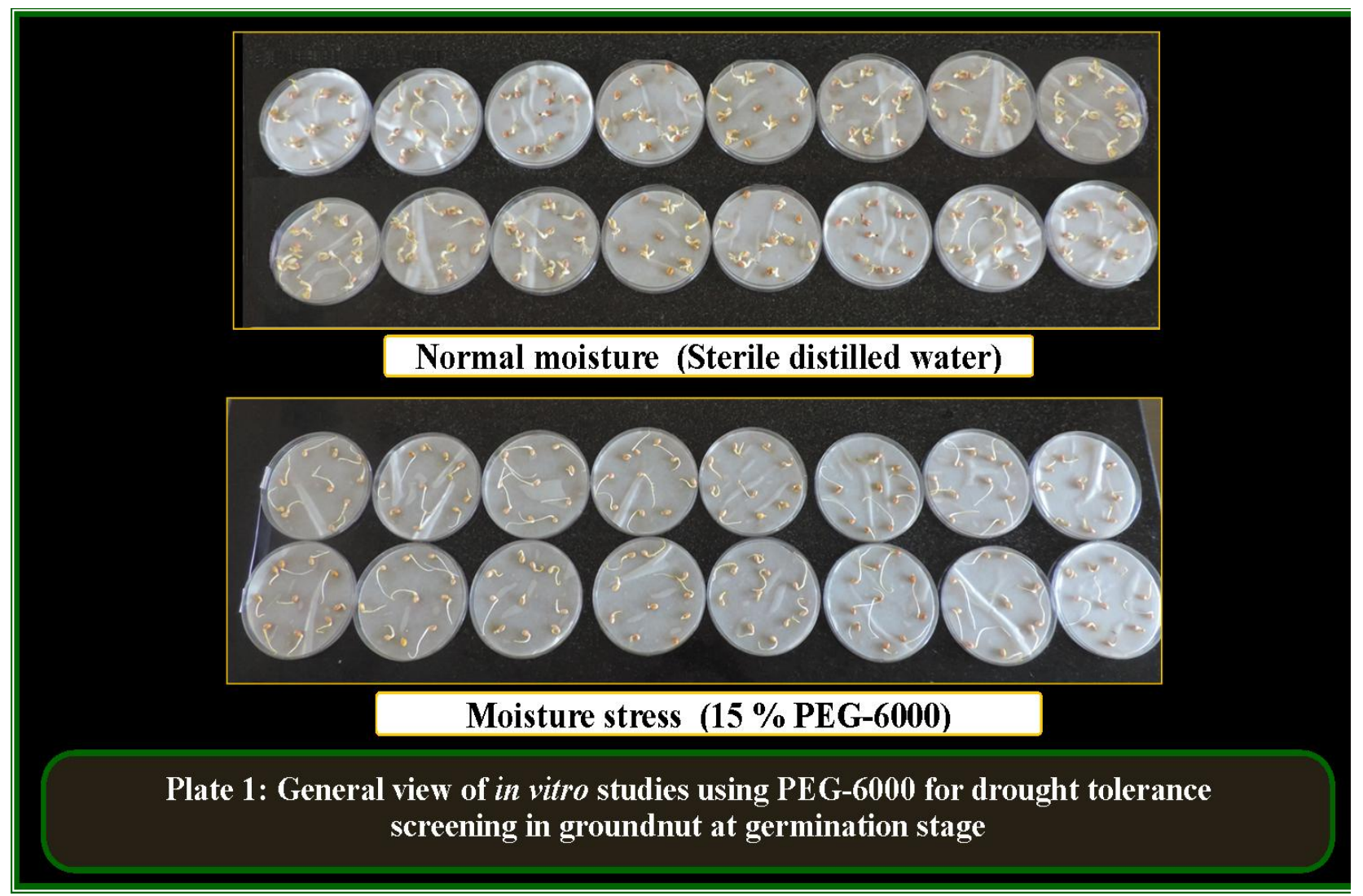


Fig.2 Comparison between broad sense heritability and genetic advance over mean (GAM) for all the characters studied in in vitro screening under stress (12\% PEG-6000) and normal condition (0 \% PEG-6000)

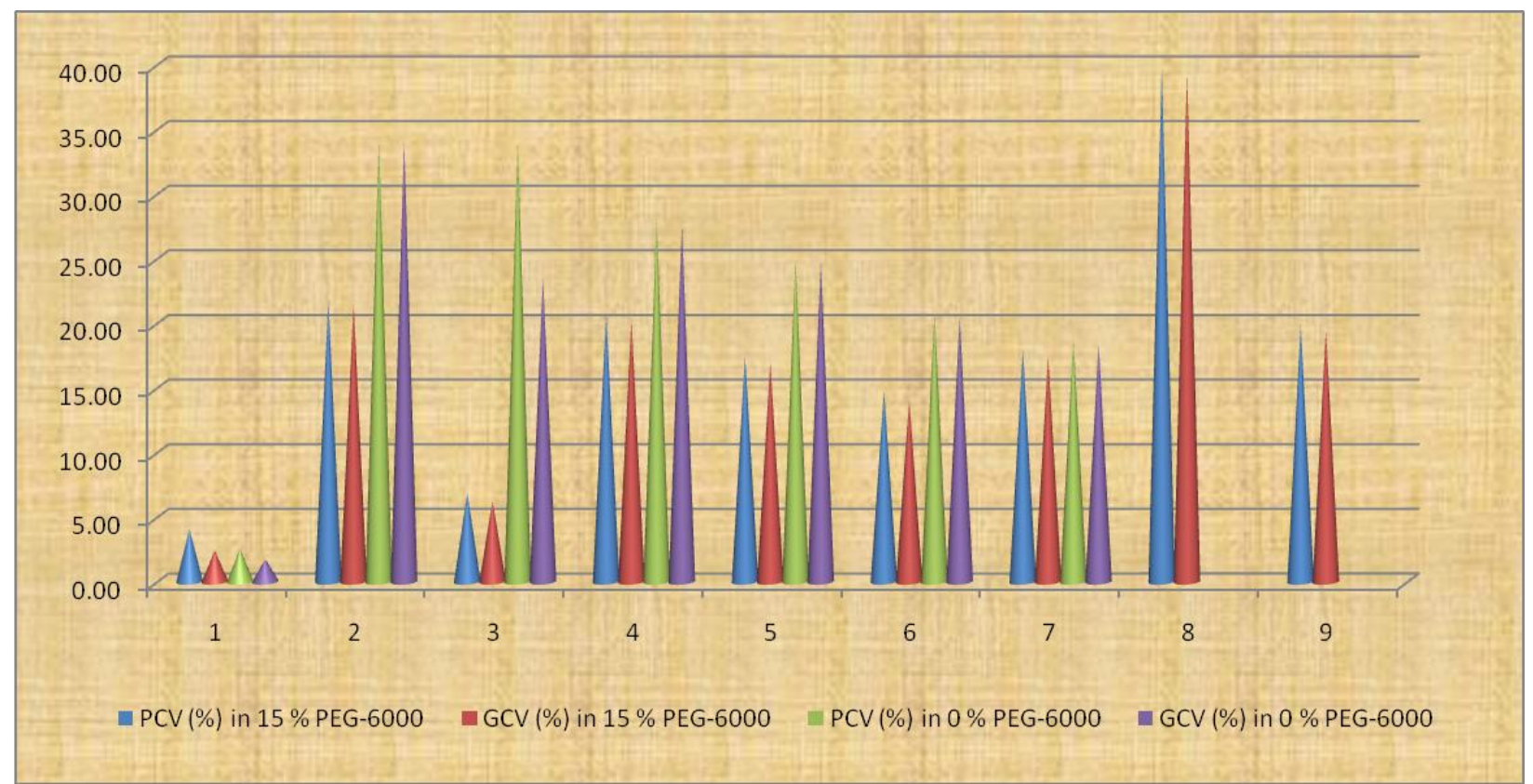

Where, 1. Germination $(\%)$

2. Root length $(\mathrm{cm})$

3. Shoot length $(\mathrm{cm})$
4. Root to shoot ratio

5. Seed vigour

6. Fresh weight (mg)
7. Dry weight (mg)

8. Root length stress tolerance index

9. Plant height stress tolerance index

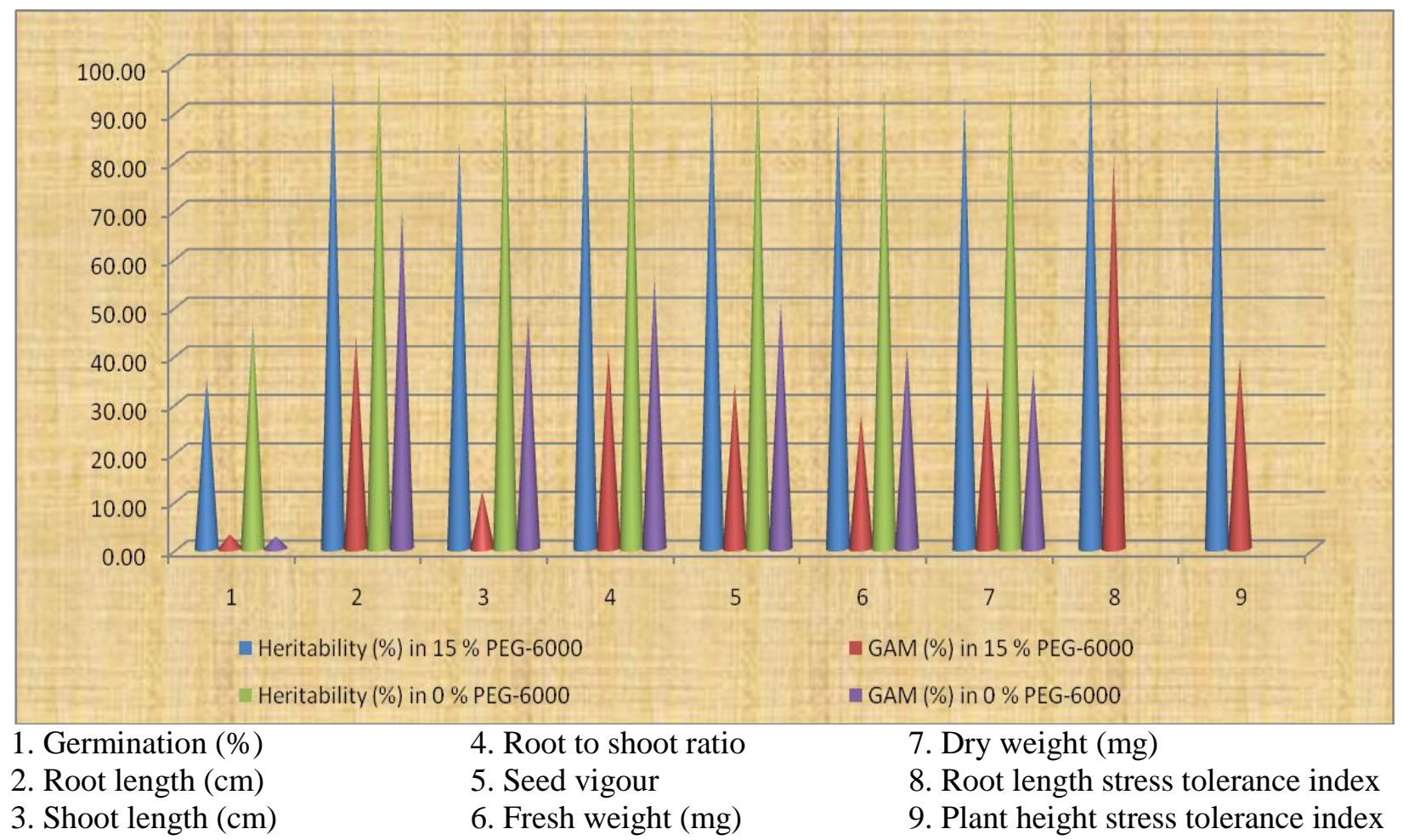


However, both of these traits exhibited high heritability coupled with high genetic advance over mean and hence may play a key role in drought tolerance screening to identify potential drought tolerant lines in groundnut. These traits can be utilized effectively for selecting genotypes with better moisture stress tolerance capacity. Similar conclusions were arrived in the research findings of Ahmad et al., (2009) and Saensee et al., (2012). The genotypes which showed superior performance for these two traits were SBT21, TMV-2, SB-T7, LOCAL-2, Dh-234, LOCAL-1, GPBD-4, VB-T14, SB-T10, SBT15, SB-T14 and VB-T31.

From all the foregoing results, it is evident and concluded that, a vast genetic variability exists among groundnut genotypes used in the present study for drought tolerance. Further, many traits considered in the in vitro screening have recorded high heritability with moderate to high genetic advance indicating the reliability of selection for these traits in identifying the drought tolerant genotypes.

\section{References}

Ahmad, S., Ahmad, R., Ashraf, M.Y., Ashraf, M. and Waraich, E.A., 2009. Sunflower (Helianthus annuus L.) response to drought stress at germination and seedling growth stages. Pak. J. Bot., 41(2): 647-654.

Burton, G.N., and Devane, E.M., 1953. Estimating heritability in tall fescue (Festuca arundianacea L.) from replicated clonal material. Agron. J., 45: 478-481.

Campos, H., Cooper, M., Habben, J.E., Edmeades, G.O. and Schussler, J.R., 2004. Improving drought tolerance in maize: A view from industry. Field Crops Res., 90: 19-34.

Cochran, W.G., and Cox, G.M., 1957. Experimental Designs. John Wiley and Sons, Inc., New York, pp. 611.

Contamutto, M., Poverene, M., Presotto, A., Alvarez, D., Lenardon, S., Rodriguez, R., Martin Sanchez, J., Fernandez Moroni, I., Giolitti, F., Garayalde, A., Haucke, A., Bellido, A. and Fraysse, M., 2010. The argentine wild Helianthus annuus L. genetic resource. Helia, 33(52): 47-62.

Coulibaly, A.M., 2013. Genetic analysis of earliness and drought tolerance in groundnut (Arachis hypogaea 1.) in Niger. Ph.D. Thesis, University of Ghana, Legon.

Cuc, M.L., Mace, E. S., Crouch, J. H., Quang, V. D., Long, D. T. and Varshney, R. K., 2008. Isolation and characterization of novel microsatellite markers and their application for diversity assessment in cultivated groundnut (Arachis hypogaea L.). Pl. Biolog., 8: 55-59.

Edmeades, G.O., Banziger, M., Schussler, J. R. and Campos, H., 2004. Improving abiotic stress tolerance in maize. Paper presented in: Arnel R. Hallauer Int. Symp. Pl. Breed., Iowa state university, Mexico City, p. 50-58.

El-midaoui, M., Serieys, H., Benbella, M., Talouizte, A., Berville, A. and Kaan, F., 2003. Effects of osmotic and water stresses on root and shoot morphology and seed yield in sunflower (Helianthus annuus L.) genotypes bred for morocco or issued from introgression with $H$. argophyllus and H. debilisnutt. Helia, 26(38): 1-16.

Errabii, T., Gandonou, C. B., Essalmani, H., Abrini, J., Idaomar, M. and Senhaji, N. S., 2008. Growth, proline and ion accumulation in sugarcane callus cultures under drought-induced osmotic stress and its subsequent relief. African J. Biotech., 5: 14881493.

Gobu, R., Harish Babu, B. N., Thimmanna, 
D., Gangaprasad, S. and Dushyantha Kumar, B. M., 2014. Standardization of in vitro screening method for drought tolerance in eggplant (Solanum melongena L.) using polyethylene glycol induced osmotic stress. Proc. $6^{\text {th }}$ Indian Hort. Congress, Coimbatore, India, p. 68.

Hanson, C.H., Robinson, H. R. and Comstock, R. S., 1956. Biometrical studies of yield in segregating population of Korean Lespedeza. Agron. J., 48: 268-272.

Hohl, M., and Schopfer, P., 1991. Water relations of growing maize coleoptiles. Pl. Physiol., 95: 716-722.

Iqbal, N., and Ashraf, M. Y., 2006. Does seed treatment with glycine betaine improve germination rate and seedling growth of sunflower (Helianthus annuus 1.) under osmotic stress. Pakistan. J. Bot., 38(5): 1641-1648.

Johnson, H.W., Robinson, H. F. and Comstock, R. E., 1955. Estimates of genetic and environmental variability in soybean. Agron. J., 47: 413-418.

Kaya, Okcu, G., Atak, M., Cikili, Y. and Kolsarici, O., 2006. Seed treatments to overcome salt and drought stress during germination in sunflower (Helianthus annuus L.). European J. Agron., 2: 291-295.

Michel, B.E., and Kaufmann, M. R., 1973. The osmotic potential of polyethylene glycol 6000. Pl. Physiol., 51: 914-916.

Rauf, A., Maqsood, M., Ahmad, A. and Gondal, A. S., 2012. Yield and oil content of sunflower as influenced by spacing and reduced irrigation condition. Sci. J. Crop Prod., 21: 4145.

Rauf, S., Sadaqat, H. A., Ahmad, R. and Khan, I. A., 2009. Genetics of root characteristics in sunflower (Helianthus annuus 1.) under contrasting water regimes. Indian $J$. Pl. Physiol., 14(4): 319-327.

Robinson, H.F., Comstock, R. E. and Harvey, V. H., 1949. Estimates of heritability and degree of dominance in corn. Agron. J., 41: 353-359.

Saensee, K., Machikowa, T. and Muangsan, N., 2012. Comparative performance of sunflower synthetic varieties under drought stress. Int. J. Agric. Biol., 14(6): 929-934.

Shankar, M., Harish Babu, B. N. and Geetha Kumari, B. N., 2016. Standardization of in vitro screening method for drought tolerance in groundnut (Arachis hypogaea L.) genotypes using polyethylene glycol (peg) 6000 induced osmotic stress. Proc. Nation. Conf. Genetics Cytogenetics, Dharwad, India. p. 61.

Subramanian, S.S., and Menon, M., 1973. Heterosis and inbreeding depression in rice. Madras Agric. J., 60: 1139.

Verslues, P. E., Ober, E. S. and Sharp, R. E., 1998. Root growth and oxygen relations at low water potentials and impact of oxygen availability in polyethylene glycol solutions. $\mathrm{Pl}$. Physiol., 116: 1403-1412.

\section{How to cite this article:}

Shankar, M., B.N. Harish Babu, R. Gobu and Sheshaiah. 2019. Studies on Genetic variability, Heritability and Genetic Advance in Groundnut (Arachis hypogaea L.) Genotypes under Normal and Osmotic Stress in In vitro Condition. Int.J.Curr.Microbiol.App.Sci. 8(05): 473483. doi: https://doi.org/10.20546/ijcmas.2019.805.056 